\title{
Improvement of Science Learning Results With Power Point Media Through Zoom Application In Class V SD IT Annida Sokaraja
}

\section{Septi Kohwati}

SDIT Annida Sokaraja

septikohwati@gmail.com

Article History

accepted 14/11/2020

approved 21/11/2020

published 26/11/2020

\begin{abstract}
The purpose of this study was to describe that student learning outcomes in science learning increased with Power Point media through the zoom application in class V SDIT Annida Sokaraja. The method used in this research is Classroom Action Research which consists of planning, implementing, observing and reflecting stages, which are carried out in 2 cycles. The subjects in this study were 18 students of grade V SDIT Annida Sokaraja. Data collection techniques using observation techniques and giving evaluation questions. Data analysis techniques were carried out to analyze the results of observations on teacher activities and student evaluation results assessment sheets to determine the increase in learning outcomes. In learning activities, teacher activities have increased from cycle I and cycle II. In the first cycle the teacher's activity reached $93 \%$ and in the second cycle the teacher's activity reached $98 \%$. While student learning outcomes in cycle I reached $86 \%$ and cycle II student activity reached $94 \%$. From these results it can be concluded that the use of power point media through the zoom application can improve the learning outcomes of fifth grade students of SDIT Annida Sokaraja. The obstacle experienced in cycle I is that students are still doing other activities outside of learning with the zoom application in progress. This problem was corrected in cycle II. From the results of the study it was concluded that the fifth grade SDIT Annida Sokaraja students experienced an increase in science learning outcomes after using Power Point media with the zoom application.
\end{abstract}

Keywords: classroom action research, learning outcomes, power point media

\section{Abstrak}

Tujuan penelitian ini untuk mendeskripsikan bahwa hasil belajar siswa dalam pembelajaran IPA meningkat dengan media Power Point melalui aplikasi zoom di kelas V SDIT Annida Sokaraja. Metode yang digunakan dalam penelitian ini adalah Penelitian Tindakan Kelas yang terdiri dari tahap perencanaan, pelaksanaan, observasi dan refleksi, yang dilaksanakan dalam 2 siklus. Subjek dalam penelitian ini adalah siswa kelas V SDIT Annida Sokaraja yang berjumlah 18 siswa. Teknik pengumpulan data dengan teknik observasi dan pemberian soal evaluasi. Teknik analisis data yang dilakukan untuk menganalisis hasil observasi terhadap aktivitas guru dan lembar penilaian hasil evaluasi siswa untuk mengetahui peningkatan hasil belajar. Pada kegiatan pembelajaran aktivitas guru mengalami peningkatan dari siklus I dan siklus II. Pada siklus I aktivitas guru mencapai 93\% dan pada siklus II aktivitas guru mencapai $98 \%$. Sedangkan hasil belajar siswa pada siklus I mencapai $86 \%$ dan siklus II aktivitas siswa mencapai 94\%. Dari hasil tersebut dapat disimpulkan bahwa penggunaan media power point melalui aplikasi zoom dapat meningkatkan hasil belajar siswa kelas V SDIT Annida Sokaraja. Hambatan yang dialami pada siklus I adalah siswa masih melakukan aktivitas yang lain di luar pembelajaran dengan aplikasi zoom berlangsung. Kendala ini diperbaiki pada siklus II. Dari hasil penelitian disimpulkan bahwa siswa kelas V SDIT Annida Sokaraja mengalami peningkatan hasil belajar IPA setelah menggunakan media Power Point dengan aplikasi zoom.

Kata kunci: penelitian tindakan kelas, hasil belajar, media power point

Social, Humanities, and Education Studies (SHEs): Conference Series https://jurnal.uns.ac.id/shes 


\section{PENDAHULUAN}

Penggunaan komputer dalam proses pembelajaran yaitu dapat digunakan sebagai media pembelajaran dengan memanfaatkan software yang ada di dalam komputer. Antara lain yaitu pemakaian teknologi baru dalam pembelajaran saat pandemi sekarang memberikan tingkat interaktivitas yang mustahil dicapai dengan bahan pembelajaran tradisional. Salah satu penggunaan teknologi informasi dalam proses pembelajaran adalah komputer beserta jaringan internetnya. Penggunaan metode yang masih konvensional, juga dalam proses pembelajarannya guru masih belum memanfaatkan media bantu atau alat peraga yang tepat. Kondisi ini berakibat pada suasana belajar yang kurang menyenangkan, motivasi belajar siswa menurun, sehingga hasil belajar siswa menjadi rendah, padahal perkembangan ilmu pengetahuan dan teknologi semakin mendorong upaya - upaya pembaharuan dalam pemanfaatan hasil-hasil teknologi dalam proses belajar.

Salah satu faktor rendahnya mutu pendidikan adalah disebabkan oleh proses pembelajaran yang masih sederhana dengan menggunakan media yang tidak variatif. Selain itu, belum diterapkan media pembelajaran yang dapat meningkatkan penyerapan informasi dalam ingatan dengan baik. Salah satu cara untuk menyimpan informasi di dalam ingatan diperlukan media pembelajaran yang tepat. Penggunaan komputer dalam proses pembelajaran yaitu dapat digunakan sebagai media pembelajaran dengan memanfaatkan software yang ada di dalam komputer. Antara lain yaitu dengan pemanfaatan microsoft powerpoint dengan berbagai variasi penyajian dan aplikasi yang dimiliki oleh microsoft powerpoint.

Guru sekurang - kurangnya dapat menggunakan alat yang murah dan efisien yang meskipun sederhana dan bersahaja tetapi merupakan keharusan dalam upaya mencapai tujuan pengajaran yang diharapkan. Microsoft Office Power Point adalah sebuah program komputer untuk presentasi yang dikembangkan oleh Microsoft, disamping Microsoft word dan excel yang telah dikenal banyak orang (Rusman dkk, 2013: 300).

Program power point merupakan salah satu software yang dirancang khusus untuk mampu menampilkan program multimedia menarik, mudah dalam pembuatan, mudah dalam penggunaan dan relatif murah, karena tidak membutuhkan bahan baku selain alat untuk penyimpanan data (Rusman dkk, 2013: 301). Microsoft Office Power Point menyediakan fasilitas slide untuk menampung pokok-pokok pembicaraan yang akan disampaikan pada peserta didik. Dengan fasilitas animasi, suatu slide dapat dimodifikasi dengan menarik. Begitu juga dengan adanya fasilitas : front picture, sound, dan effect dapat dipakai untuk membuat suatu slide yang bagus. Sehingga, mengakomodasi sesuai dengan modalitas belajar siswa. Program ini dapat mengakomodasi siswa yang memiliki tipe visual, auditif, maupun kinestetik (Rusman dkk, 2013: 297).

Menurut Asmadji (2012) media pembelajaran power point dapat meningkatkan aktivitas siswa dan guru dalam proses belajar siswa, karena penggunaan media power point siswa akan lebih aktif mengikuti pembelajaran. Hasil belajar pada penilaian harian sebelum penelitian di kelas V SDIT Annida, siswa yang mencapai kriteria ketuntasan minimal masih di bawah $80 \%$. Hal ini terjadi selain penggunaan metode yang masih konvensional, juga dalam proses pembelajarannya guru masih belum memanfaatkan media bantu atau alat peraga yang tepat. Masalah yang paling penting untuk segera dipecahkan atau merupakan akar masalah yang sesungguhnya yaitu sebagaian siswa kurang aktif dalam pembelajaran karena Guru tidak menggunakan 
media. Dari data yang diperoleh maka diharapkan dengan penggunaan media pembelajaran Power point dapat meningkatkan hasil belajar siswa, karena penggunaan media pembelajaran power point diharapkan lebih menarik dan memberikan pengalaman yang nyata yang lebih tahan lama dan sulit dilupakan siswa.

Fokus utama pada penelitian ini adalah untuk meningkatkan hasil belajar IPA dengan Media Power Point pada Aplikasi Zoom di Kelas V SDIT Annida Sokaraja. Rumusan masalah pada penelitian ini adalah bagaimana menerapkan media Power Point untuk meningkatkan hasil belajar dalam pembelajaran IPA melalui Aplikasi Zoom di Kelas V SDIT Annida Sokaraja rumusan masalah pada penelitian ini adalah bagaimana menerapkan media Power Point untuk meningkatkan hasil belajar dalam pembelajaran IPA melalui Aplikasi Zoom di Kelas V SDIT Annida Sokaraja. Penelitian ini bertujuan untuk mendeskripsikan bahwa hasil belajar siswa dalam pembelajaran IPA meningkat melalui Media Power Point pada Aplikasi Zoom di Kelas V SDIT Annida Sokaraja.

\section{METODE}

Pelaksanaan Penelitian ini merupakan Penelitian Tindakan Kelas (PTK) dengan menggunakan deskriptif kualitatif. Menurut Arikunto, (2006:97) mengatakan bahwa PTK adalah penelitian yang dilakukan oleh guru di kelas atau di sekolah tempat ia mengajar dengan penekanan dan penyempurnaan atau peningkatan proses pembelajaran. Sedangkan menurut Aqib (2011), penelitian tindakan kelas adalah penelitian yang dilakukan oleh guru di kelasnya sendiri melalui refleksi diri dengan tujuan untuk memperbaiki kinerjanya sehingga hasil belajar siswa meningkat. Penelitian dilakukan di SDIT Annida yang beralamat di Jalan Soepardjo Roestam Perumahan Ketapang Indah Blok D4 Desa Sokaraja Kulon Kecamatan Sokaraja, Kabupaten Banyumas, Jawa Tengah. Waktu penelitian dimulai pada bulan Oktober sampai dengan November 2020. Subjek penelitian adalah siswa kelas V SDIT Annida yang berjumlah 18 siswa terdiri dari 8 siswa laki-laki dan 10 siswa perempuan.

Pelaksanaan pengumpulan data dimulai menjelang penelitian tindakan kelas dan pada setiap siklus dimulai dari awal sampai akhir siklus II. Teknik pengumpulan data melalui observasi menggunakan alat indera dan mencatat segala sesuatu selama pembelajaran berlangsung. Observasi adalah suatu teknik yang dilakukan dengan cara mengadakan pengamatan secara teliti dan sistematis (Arikunto, 2006: 133). Observasi dilakukan oleh teman sejawat peneliti pada saat peneliti menyampaikan proses pembelajaran aktivitas guru di kelas dengan tujuan mendapatkan hasil pengamatan berupa keaktifan siswa dalam kegiatan belajar. Data hasil observasi dicatat dalam lembar observasi aktivitas guru dan siswa.

Tes adalah serentetan pertanyaan atau latihan serta alat lain yang digunakan untuk mengukur keterampilan, pengetahuan, intelegensi, kemampuan atau bakat yang dimiliki oleh individu atau kelompok (Arikunto, 2002: 127). Tes diberikan untuk mengetahui hasil belajar siswa. Tes yang diberikan berupa pilihan ganda berjumlah 5 nomor tentang IPA materi rantai makanan.

Teknik analisis data merupakan cara yang digunakan untuk mengolah data yang berhubungan erat dengan rumusan masalah. Setelah semua data terkumpul, maka langkah selanjutnya yaitu menganalisis data, sehingga mendapatkan suatu kesimpulan yang nyata. Untuk menganalisis data, peneliti menggunakan metode deskriptif kuantitatif dan deskriptif kualitatif.

Arikunto (2006:131) menjelaskan bahwa data deskriptif kuantitatif adalah data berupa nilai hasil belajar siswa. Sedangkan data deskriptif kualitatif adalah data yang berupa informasi berbentuk kalimat yang memberi gambaran tentang ekspresi siswa tentang tingkat pemahaman terhadap suatu mata pelajaran (kognitif), pandangan sikap siswa terhadap media pembelajaran yang baru (afektif), aktivitas siswa 
mengikuti pelajaran, perhatian, antusias dalam belajar, kepercayaan diri, motivasi belajar dan sejenisnya, dapat dianalisis secara kualitatif. Keberhasilan dan kegagalan dalam belajar mengajar merupakan sebuah ukuran atas proses pembelajaran. Apabila merujuk pada rumusan operasional keberhasilan pembelajaran, maka pembelajaran dikatakan berhasil apabila: (1) Aktivitas guru pada saat pembelajaran mencapai persentase sebesar > 80\%; (2) hasil belajar siswa adalah sebanyak $>80 \%$ siswa memperoleh nilai $>75$

\section{HASIL DAN PEMBAHASAN}

Berdasarkan hasil diskusi dengan teman sejawat bahwa ketidaktuntasan siswa dalam proses pembelajaran IPA dengan materi Rantai Makanan kelas $\mathrm{V}$ di SDIT Annida Sokaraja, Kecamatan Sokaraja, Kabupaten Banyumas, disebabkan oleh: aktivitas siswa yang masih kurang dalam pembelajaran prasiklus adalah mengerjakan LKPD, mengumpulkan tugas, membuat kesimpulan materi, melakukan kegiatan di luar pembelajaran, dan menjawab pertanyaan guru.

Berdasarkan temuan masalah diatas, maka langkah yang ditempuh guru untuk meningkatkan hasil belajar adalah menggunakan media pembelajaran yang tepat. Penggunaan Microsoft Office Power Point dalam pembelajaran menyediakan fasilitas slide untuk menampung pokok-pokok pembicaraan yang akan disampaikan pada peserta didik. Dengan fasilitas animasi, suatu slide dapat dimodifikasi dengan menarik. Begitu juga dengan adanya fasilitas : front picture, sound, dan effect dapat dipakai untuk membuat suatu slide yang bagus. Sehingga, mengakomodasi sesuai dengan modalitas belajar siswa. Program ini dapat mengakomodasi siswa yang memiliki tipe visual, auditif, maupun kinestetik (Rusman dkk, 2013: 297).

Berdasarkan hasil penelitian menunjukkan bahwa hasil belajar IPA siswa tentang rantai makanan mengalami peningkatan. Terlihat dalam tabel berikut ini.

Tabel 1. Hasil Belajar dan Peningkatan Nilai Rata - Rata

\begin{tabular}{|c|c|c|c|c|c|c|c|}
\hline \multirow[t]{2}{*}{ No } & \multirow[t]{2}{*}{ Ketuntasan } & \multicolumn{2}{|c|}{ Pra Siklus } & \multicolumn{2}{|c|}{ Siklus I } & \multicolumn{2}{|c|}{ Siklus II } \\
\hline & & Jumlah & $\%$ & Jumlah & $\%$ & Jumlah & $\%$ \\
\hline 1 & Tuntas & 10 & 56 & 14 & $78 \%$ & 17 & $94 \%$ \\
\hline 2 & Belum Tuntas & 8 & 44 & 4 & $22 \%$ & 1 & $6 \%$ \\
\hline 3 & Nilai rata -rata & 68 & & 78 & & & \\
\hline
\end{tabular}

Berdasarkan tabel di atas dapat kita lihat bahwa pada Pra Siklus hanya $56 \%$ siswa yang meraih ketuntasan, $78 \%$ pada siklus I, pada Siklus II sebanyak $94 \%$. Ini menunjukkan bahwa peningkatan yang signifikan apabila kita menggunakan media pembelajaran yang tepat sehingga siswa dapat belajar dengan semangat dan meraih prestasi yang kita harapkan.

Pada nilai rata - rata juga mengalami peningkatan yang signifikan, nilai rata rata pada pembelajaran awal 68 , pada siklus I mengalami peningkatan yaitu 78 , pada perbaikan pembelajaran siklus II menjadi 88. 
Dari tabel 1 dari hasil evaluasi pembelajaran awal hingga perbaikan pembelajaran siklus II mata pelajaran IPA materi rantai makanan jika disajikan dalam bentuk diagram maka dapat dilihat pada gambar 1 berikut.

Gambar 1. Hasil Belajar

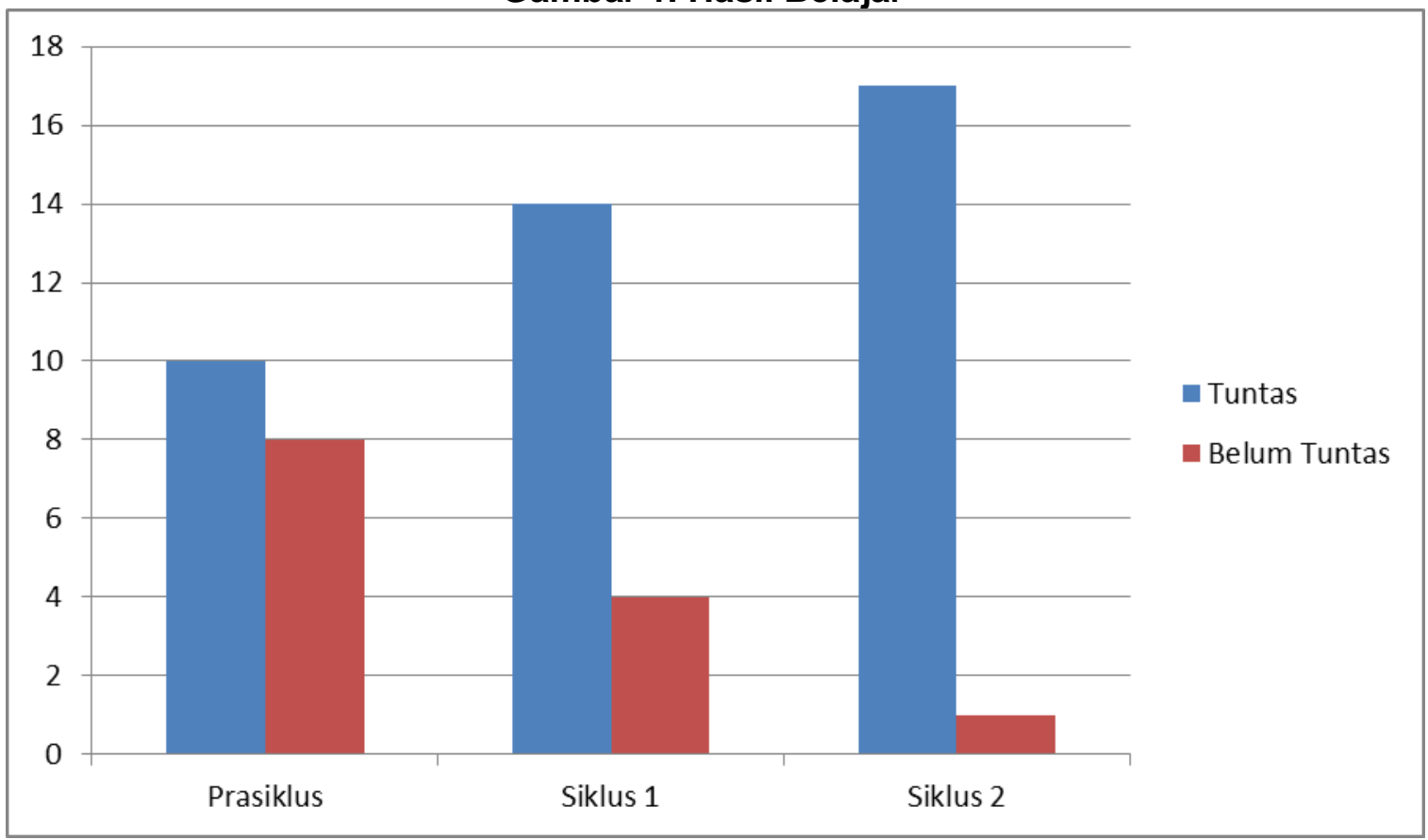

Gambar 2. Peningkatan Nilai Rata-rata

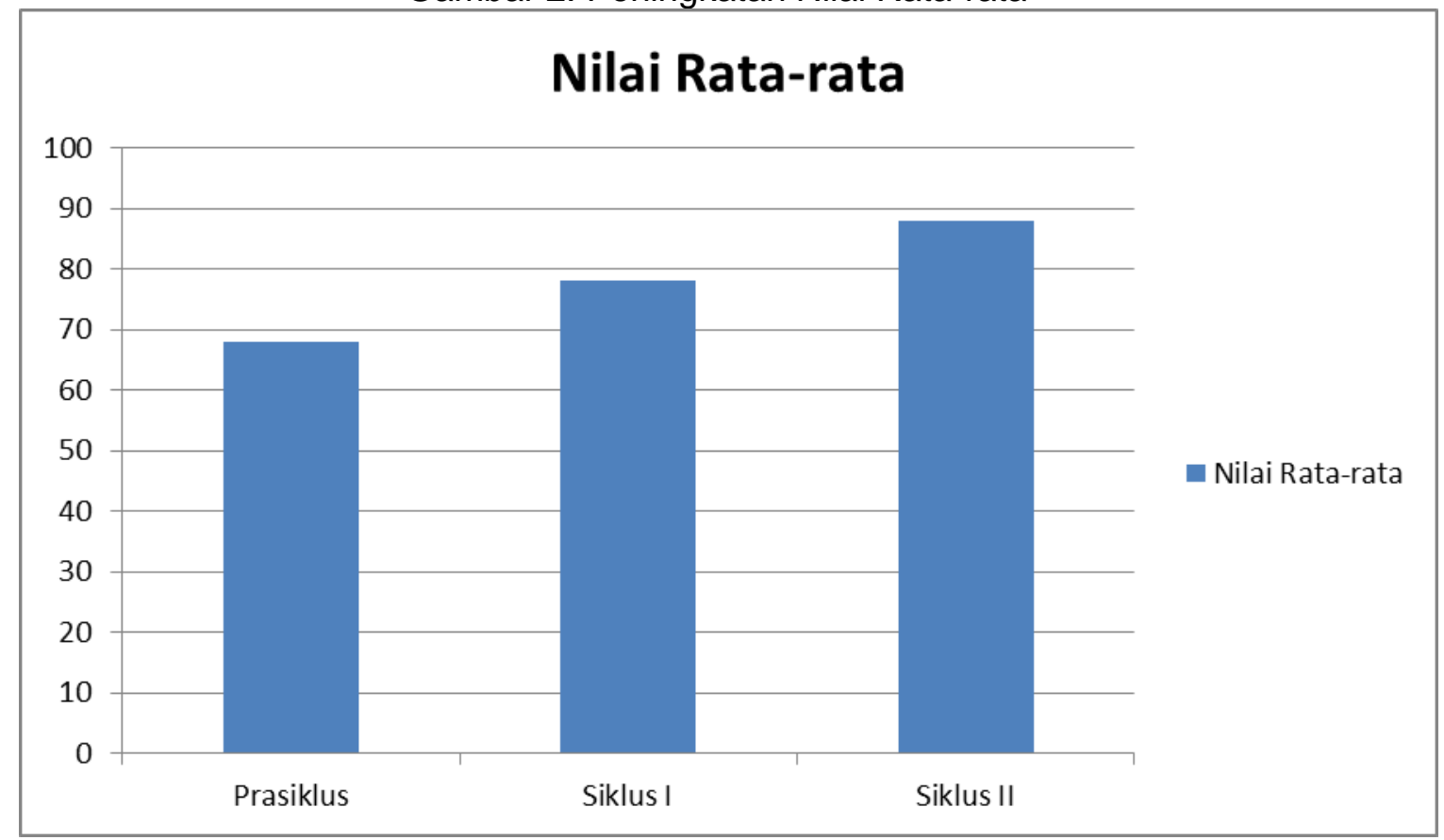

Pada gambar 2 di atas menunjukkan grafik peningkatan nilai rata - rata mata pelajaran IPA dengan materi Rantai Makanan di kelas V di SDIT Annida Sokaraja, Kecamatan Sokaraja, Kabupaten Banyumas, bahwa sebelum perbaikan pembelajaran 
nilai rata - rata 68 , pada perbaikan siklus I nilai rata - rata 78 kenaikan nilai rata - rata 10. Pada perbaikan pembelajaran siklus II nilai rata - rata 88 , kenaikan nilai rata - rata dari perbaikan pembelajaran siklus I ke perbaikan siklus II yaitu 10 .

\section{SIMPULAN}

Setelah peneliti melaksanakan perbaikan pembelajaran melalui pembelajaran siklus I, siklus II dengan materi Rantai Makanan di kelas V SDIT Annida Sokaraja Kecamatan Sokaraja, Kabupaten Banyumas, maka peneliti dapat mengambil kesimpulan bahwa upaya meningkatkan hasil belajar IPA dengan media power point melalui aplikasi zoom siswa kelas V SDIT Annida telah berhasil meningkatkan hasil belajar siswa.

Peningkatan ini terjadi pada siklus I dan siklus II dengan bukti adanya peningkatan pada : menggunakan media pembelajaran power point dapat meningkatkan pemahaman dan antusiasme siswa terhadap materi IPA tentang rantai makanan sehingga meningkatkan hasil belajar siswa. Hal ini terbukti dengan meningkatnya hasil belajar siswa yang pada pra siklus ada 10 siswa atau 56\% dari 18 siswa yang tuntas dengan nilai rata-rata 68 . Pada perbaikan pembelajaran siklus I meningkat, siswa yang memenuhi kriteria tuntas menjadi 14 siswa atau $78 \%$ dari jumlah 18 siswa dengan nilai rata-rata 78, pada perbaikan siklus II enjadi 17 siswa atau $94 \%$ dari jumlah 18 siswa dengan nilai rata-rata 88 dan pada perbaikan siklus III menjadi 6 anak atau 100\% dengan nilai rata-rata 88,63.

\section{DAFTAR PUSTAKA}

Aqib, Zainal, dkk. 2011. Penelitian Tindakan Kelas untuk Guru SD, SLB, dan TK. Bandung: Yrama Widya.

Arikunto, Suhardjono dan Supardi. 2006. Penelitian Tindakan Kelas. Jakarta: Bumi Aksara.

Asmadji, Herry. 2012. Penggunaan Media Pembelajaran Power Point Untuk Meningkatkan Hasil Belajar IPA Materi Pesawat Sederhana Siswa Kelas VC SDN Ketabang I Surabaya. Surabaya: Jurnal Universitas Negeri Surabaya

Rusman, dkk.2013. Model-model Pembelajaran (Mengembangkan Profesionalisme Guru). Jakarta: PT Raja Grafindo Persada

Tarsito. Susanto, Ahmad. 2014. Teori Belajar dan Pembelajaran di Sekolah Dasar. Jakarta: Kencana. 